\title{
MULTINATIONAL CLASSROOM AS THE CURRENT TREND IN HIGHER EDUCATION INTERNATIONALIZATION AT THAI NGUYEN UNIVERSITY
}

\section{Do Le Ha}

Thai Nguyen University

\begin{tabular}{|c|c|c|}
\hline \multicolumn{2}{|c|}{ ARTICLE INFO } & ABSTRACT \\
\hline Received: & $16 / 4 / 2021$ & In the world of global challenges, foreign universities have \\
\hline Revised: & 24/5/2021 & $\begin{array}{l}\text { implemented many strategies to attract Vietnamese students to come to } \\
\text { study, and many international students choose Vietnamese universities }\end{array}$ \\
\hline Published: & $24 / 5 / 2021$ & as study destinations, therefore, the multinational classroom has been \\
\hline & & formed. In light of researching the role, the necessity of multinational \\
\hline \multicolumn{2}{|l|}{ KEYWORDS } & classrooms in the trend of higher education internationalization, the \\
\hline \multicolumn{2}{|c|}{ Multinational classroom } & improved points of conducting \\
\hline \multicolumn{2}{|c|}{ University's internationalization } & In this article, we use the research methodology as practical \\
\hline \multicolumn{2}{|c|}{ Integration } & observations, case studies, and in-depth interviews with Vietnamese, \\
\hline \multicolumn{2}{|l|}{ Multicultural } & research results have suggested some solutions to improve quality, \\
\hline \multicolumn{2}{|l|}{ Language } & $\begin{array}{l}\text { efficiency and created motivation for the university's } \\
\text { internationalization such as renovating the university management, } \\
\text { creating the conditions for lecturers to develop the capabilities, } \\
\text { increasing classroom interaction and exploring a new culture. }\end{array}$ \\
\hline
\end{tabular}

\section{LỚP HỌC PHẦN ĐA QUỐC GIA TRONG XU THẾ QUỐC TẾ HÓA GIÁO DỤC ĐẠI HỌC TẠI ĐẠI HỌC THÁI NGUYÊN}

Đỗ Lệ Hà

Đại học Thái Nguyên

\begin{tabular}{|c|c|c|}
\hline THÔNG TIN B & I BÁO & TÓM TẮT \\
\hline Ngày nhận bài: & $16 / 4 / 2021$ & Trong bối cảnh toàn cầu hóa mạnh mẽ, các trường đại học nước ngoài \\
\hline Ngày hoàn thiện: & $24 / 5 / 2021$ & $\begin{array}{l}\text { thực hiện nhiều chính sách thu hút sinh viên Việt Nam đến học tập và } \\
\text { cưng cô nhiều sinh viên quốc tề chọn các trường đại học của Việt Nam là }\end{array}$ \\
\hline Ngày đăng: & $24 / 5 / 2021$ & điểm đến để học tập và trải nghiệm văn hóa, từ đó, lớp học phần đa quốc \\
\hline \multirow{2}{*}{\multicolumn{2}{|c|}{ TÙ KHÓA }} & gia được hình thành. Với mục tiêu nghiên cứu vai trò, sự cân thiêt của \\
\hline & & $\begin{array}{l}\text { lợp học phân đa quôc gia trong xu the quôc te hoa giáo dục đại học, bà1 } \\
\text { báo đã tâp trung phân tích những thuân lợi, khó khăn và những điểm cần }\end{array}$ \\
\hline \multicolumn{2}{|c|}{ Lớp học phần đa quốc gia } & cải tiến trong quá trình tổ chức đào tạo các lớp học phần này. Bài báo đã \\
\hline \multicolumn{2}{|l|}{ Quốc tế hóa } & sử dụng phương pháp nghiên cứu định tính thông qua quan sát thực tế, \\
\hline \multicolumn{2}{|l|}{ Hội nhập } & nghiên cứu tình huông và phỏng vân sâu giảng viên, sinh viên Việt Nam \\
\hline \multicolumn{2}{|l|}{ Đa văn hóa } & $\begin{array}{l}\text { và quôc tê tại Đại học Thái Nguyên. Kêt quá nghiên cứu đã đê xuât một } \\
\text { số giải pháp nhắm nâng cao chât lương, hiêu quả và tao đông lưc cho }\end{array}$ \\
\hline \multicolumn{2}{|l|}{ Ngôn ngữ } & $\begin{array}{l}\text { quá trình quốc tế hóa nhà trường như đổi mới quản lý, tạo các điều kiện } \\
\text { để giảng viên phát triển năng lực bản thân, tăng cường tương tác trong } \\
\text { lớp học và cơ hội khám phá các nền văn hóa mới. }\end{array}$ \\
\hline
\end{tabular}

DOI: https://doi.org/10.34238/tnu-jst.4380

Email:doleha@tnu.edu.vn 


\section{Introduction}

There is an important relationship between culture and education. Nowadays, with the globalization of education, students have more chances to obtain international experiences even if they do not need to go abroad. Chen \& Sujarittanonta [1] point out those students who study in a local degree program, also study together with foreign classmates. Those classrooms make the first brick for education and culture exchange. However, the difference in physical and cultural backgrounds is the reason for misunderstanding and cultural conflict between local and foreign students. Crose [2] says that "International students bring differing cultural experiences, expectations, and learning styles to the higher education classroom that allow for new perspectives to be introduced".

On other research, Alsubaie [3] says "classrooms are becoming increasingly multicultural, and these lead to new challenges for teachers. Traditionally, students coming into the multicultural classroom are at a deficit because they must learn how to navigate unfamiliar people, their cultures, and language." McAllister and Irvine [4] argue that teachers in multicultural classrooms "face increasing challenges in providing an appropriate classroom environment and high standards of instruction that foster the academic achievement of all students."

Safipour et al. show that "In international higher education, a unique educational setting is established, called the international classroom, including host students, international students, and academic staff. International students who study abroad usually attempt to increase their intercultural competence and cultural awareness during the course of their education. However, the overall experience of learning in the international classroom can be challenging if students (and teachers) are not prepared for the international education" [5].

In recent years, universities in Vietnam have become a destination for international students. A classroom including Vietnamese and international students is considered normal. A multinational classroom is a place that provides both local and international students with new learning experiences, not only in terms of career academic, and skills but also opportunities to understand more about the cultures of countries around the world. This study about those classrooms sheds some light on:

1. What is the importance of globalization for higher education?

2. What are the advantages and disadvantages of implementing multinational classroom?

3. What are the requirements to implement multinational classroom?

4. What are suggestions to deploy these classes for the university's international integration process effectively?

\section{Methods}

Participants of the study were 77 students of one classroom taught in English and one taught in Vietnamese and 15 lecturers at International School, Thai Nguyen University. The age of students ranges from 18 to 22 years old. Out of 77 selected students, there were 11 foreign students coming from 5 countries as Nigeria, Laos, Cambodia, Myanmar, and Timor - Leste.

All data were collected by direct interview with the lecturers and foreign students, observation of the classroom and gathered from secondary sources such as science direct, and Google scholar, etc... First of all, we made an interview plan with a list of questions and interviewees. We also conducted an interview protocol and guide for interviewees. Fifteen questions were checked carefully to ensure easy contents for students to understand. The keywords used to conduct the questions were an international classroom, exchange students, learning and teaching culture, the trend of international education, advantages and disadvantages of the multinational classroom, etc...With the same questions, we interviewed and collected the data from 77 students, and then analyzed and solicited feedback from interviewees. 
Besides, the qualitative articles were selected since the main focus of this study was to present the state of knowledge and the analysis of the data. The qualities of articles were assessed by reading them in their entirety from the abstract to the conclusion section. All the included articles were reviewed carefully and the meaning identified.

\section{Results and discussion}

\subsection{The trend of international education}

In the context of increasingly extensive globalization, universities are aware of the importance and benefits of international cooperation to their existence and development so that the universities invest to implement a variety of international cooperation activities. Attracting international students, building an international learning environment is considered the most important task of international cooperation. The multinational classroom is established and considered an important factor to implement international integration strategies on the quality of training, helping students enhance their understanding, develop their intercultural culture skills, and prepare for the students the necessary conditions to become global citizens.

According to statistics, the number of international students globally constantly increased from 3.9 million from 2011 to 4.6 million in 2015, and more than half of international students concentrated in a few countries such as the USA, UK, Australia, France [6], [7]. In 2019, the number of international students came to study in the US was more than 1 million, making up $5.5 \%$ of the total number of students [7], [8], and more than 458 thousand in the UK, a proportion of $19.6 \%$ of the total number of students [6]. Compared to above countries, the number of international students coming to Vietnam is still quite modest with about 21,000 focusing on undergraduate, master, doctoral degrees, and internship. Most of them are from "neighboring countries" such as Laos, Cambodia, China, etc...; a few others come from developed countries such as the US, Canada, Korea, Australia, France [7], [9]. Although the number of international students is small, multinational classrooms are not rare at Vietnamese universities.

\subsection{The Multinational classroom at Thai Nguyen University: advantages and disadvantages}

Established in 1994, Thai Nguyen University (TNU) is a regional, multi-disciplinary, multilevel and key university in Vietnam with more than 2,600 teaching staff implementing 141 undergraduate majors; 60 master programs and 32 doctoral programs in many fields of science. In recent years, TNU has constantly developed international cooperation in the fields of training, scientific research and technology transfer with a focus on experience and creativity for students [10].

Currently, TNU has strongly cooperated relations with over 100 countries, territories, and international organizations, including prestigious universities such as the University of Buffalo, University of Oklahoma, University of Hawaii, University of California (USA); University of Manchester, University of the West of England, University of Nottingham (UK); Swinburne University, Curtin University, Edit Cowan University (Australia); Seoul National University, Kyongpook National University (Korea), Thanh Hoa University (China), National University of Singapore, etc.... The university has been implementing 9 advanced programs, 14 joint training programs. TNU is training 1.374 international students from more than 20 countries (Korea, China, Thailand, Switzerland, Laos, Cambodia, Timo Leste, etc.), of which, $82 \%$ of international students study in Vietnamese programs, 18\% rest study programs are taught in English [10].

\subsubsection{Advantages}

Firstly, the multinational classroom can boost for enrollment. Vietnamese students feel more excited when they study with international students, especially in the same classroom with 
international students. This is an opportunity for Vietnamese students to experience the difference in international students' studying methodology and the way of thinking in academics.

Secondly, the multinational classroom enriches the cultural diversity in universities. International students have chances to show off their country's culture, also integrate with Vietnamese culture, and conversely, experience a multinational environment. In addition, Vietnamese students also have opportunities to interact with diverse cultures, to compare and build a more diverse world view. This helps forge Vietnamese students to be confident and adaptive when working in an international environment.

Finally, training international students also brings income to the university. The learning and living needs of international students are suitable. In addition, international students are the bridge to promote and attract other students to study in the future.

\subsubsection{Disadvantages}

Firstly, language is considered the biggest challenge and barrier not only for foreign students but also for Vietnamese students. In multinational classrooms, the language is a means of assimilating into a new culture and learning environment. However, language is also the biggest barrier that requires all components of the classroom to overcome, especially international students, specifically:

- In classrooms taught in English, Vietnamese students cannot use English fluently after 01 years (about 1,200 hours), especially to study specialized courses. In addition, the university has international English standard entry requirements after one year of study, but only a few students can achieve. The rest one needs to pass the internal assessment of the university to be able to apply for the course. Because of this, the student's English level is not equal. In particular, there are some students who cannot study English.

- In classrooms taught in Vietnamese, international students find it difficult to participate in group discussions, even without a role in the discussion group. D. Santos - 1st year student and Akpaquat - 3rd year student said that they were often arranged to join the discussion group, but it was very difficult for them to work with others in the group. They had difficulty trying to express their ideas, over time they joined as formal fashion. Lucio, A. De Deus - final year student felt insecure when answering lecturers' questions in Vietnamese, only confidently answering questions in English. W. Nunes and Krystle M. R - 1st year student got the problem of using grammar. They said, "Trying to write essay properly grammatically is a big challenge. I try to remember the grammar structures but when I present, I always laugh at my classmates. I often use short sentences and simple meanings. I find it very difficult, but nonetheless this is my 2 nd language."

Secondly, international students have difficulties adapting to a new learning environment, educational thinking, teaching methodology, as well as interacting with Vietnamese lecturers and students. Sometimes, they feel isolated when presenting to the group and working in groups. As for Vietnamese lecturers and students, they have to change teaching and learning methodology, adapting to independent critics, and handling different learning situations.

Thirdly, learning culture is also a barrier for students. The majority of Vietnamese students studying at TNU come from the northern midland and mountainous provinces. They both adapt to a new learning environment different from high school and studying with foreign students is really a big challenge. "I am very nervous when speaking English in the classroom, very scared while the international students answer confidently, even when they answer incorrectly" (Đ.TL 1st year student). "Due to cultural differences, the way of expressing cultural differences, expressing ideas - logic is also different. Foreign students easily express their ideas in a concise and straightforward manner and go straight to the problems while Vietnamese students often go round and lack confidence when presenting their personal opinions" (TMH - 3rd year). 


\subsection{Discussion}

The interview results show that language challenges, classroom interactions, facilitating discussion, and experimental studies are the main factors impacting the renovation of the university management and conditions of learning environment.

It is true that nowadays, the multinational classroom plays a crucial role in establishing an internationalization of the university, so that, it needs to renovate quality management and administration modernization. The university needs to cognize the change of strategies, the constant updating of skills, and the incorporation of new management tools. In order to do that, the university renews its administration by applying new technology application, training management, scientific research methodology, and investment in facilities. In addition, the university implements a variety of strategies to build a positive classroom environment where the lecturers have a chance to implement new teaching methods, and enhance students' activeness, especially, encourage students to increase discussion time, show their culture and knowledge, and apply their culture and knowledge of real-world situations.

Next, the university creates all conditions for lecturers to develop their own capabilities, continuously improve their professional knowledge and improve languages capacity, actively renew thinking and teaching methodology, using of advances of information technology in teaching and identifying knowledge models in the digital age. In particular, the lecturers should constantly updating new information, opportunities to experience a variety of cultures around the world and improve their own practical experience to improve their quality of teaching.

Then, the university has a strategy to increase classroom interaction. The result of the lecturer and student, Vietnamese and international students' interaction will determine the success of the classroom. The classroom is also the place where initiative and creativity in learning are shown most clearly. Lecturers do not direct students to their cultural background, but must find appropriate teaching methodology to help students become aware of cultural diversity. The lecturers will guide students as the instructor, directs the operations, effectively designs the tasks and ensures all students are involved in the task. They should implement key interactive methodology such as active lecturing, lesson logic questions and answers, group discussions, device Vietnamese and international students into small groups to work together. The lecturers encourage students to increase asking questions, presenting tasks in different ways, discussing learning difficulties as well as differences in knowledge approaches. Lecturers also need to apply information technology and modern teaching facilities in the simulation to help students realize the diversity between different cultures. Lecturers and students also have to strictly follow the rules of the class. The duties of a lecturer is not only teaching but also creating a culture, in which team spirit is always at the center.

Finally, the lecturers use language barriers into opportunities to explore a new culture. When students of different languages study in a multinational classroom, language is now seen as a bridge to integrating into the new culture and learning environment. However, both teachers and students have to overcome the fear of communication, confidence in expressing their own opinions, and misunderstanding between speakers and listeners. At this point, the role of the lecturers' connection is very important; understanding the language ability of each student will help the lecturer organize the class better. They should choose teaching content to ensure fit, increase the use of modern teaching techniques and equipment, and practical images to support the lecture. In the lecture process, the lecturers must have flexibility and flexibility in promoting students' initiative.

\section{Conclusion}

This article has focused on research to point out the advantages and disadvantages of deploying multinational classroom at Thai Nguyen University, as well as proposing four 
solutions to effectively deploy that classroom. With the speed of international integration, how to deploy of the multinational classroom will attract the number of foreign students coming to study at the Thai Nguyen University, from that Thai Nguyen University has an international environment.

\section{REFERENCES}

[1] J. S. Chen and L. Sujarittanonta, "Enhancing Intercultural Collaborative Learning in a Multinational Classroom: Case of Taiwan," Asian Social Science, vol. 10, no. 15, pp. 221-228, 2014.

[2] B. Crose, "Internationalization of the Higher Education Classroom: Strategies to Facilitate Intercultural Learning and Academic Success," International Journal of Teaching and Learning in Higher Education, vol. 23, pp. 388-395, 2011.

[3] M. A. Alsubaie, "Examples of Current Issues in the Multicultural Classroom," Journal of Education and Practice, vol. 6, no.10, pp. 86-89, 2015.

[4] A. Chouari, "Cultural Diversity and the Challenges of Teaching Multicultural Classes in the TwentyFirst Century," Arab World English Journal, vol.7, no. 3, pp. 3-17, 2016.

[5] J. Safipour, S. Wenneberg, and E. Hadziabdic, "Experience of Education in the International Classroom-A Systematic Literature Review," Journal of International Students, vol. 7, no. 3, pp. 806824, 2017.

[6] United Nations, Global Education Monitoring, Japan International Cooperation Agency, "Global Education Monitoring Report," 2019, pp. 3-9.

[7] The United Nations, Educational, Scientific and Cultural Organization and UNESCO Bangkok, "The International Mobility of Students in Asia and the Pacific," 2013, pp. 1-5.

[8] US Embassy Hanoi, "Public affairs section," 2018. [Online]. Available: https://vn.usembassy.gov/vi/pr14112018/ [Accessed November 25, 2020].

[9] Ministry of Education and Training, "Report Summary of School Year 2018-2019, implementation of Tasks for School Year 2019-2020," 2019, p. 14

[10] Thai Nguyen University, "Report Summary of International Cooperation," 2019, pp. 1-4. 